\title{
Increased content of hydrogen peroxide in the expired breath of cigarette smokers
}

\author{
D. Nowak, A. Antczak, M. Krol, T. Pietras, B. Shariati, P. Bialasiewicz, \\ K. Jeczkowski, P. Kula
}

Increased content of hydrogen peroxide in the expired breath of cigarette smokers. D. Nowak, A. Antczak, M. Krol, T. Pietras, B. Shariati, P. Bialasiewicz, K. Jeczkowski, P. Kula. @ERS Journals Ltd 1996.

ABSTRACT: Cigarette smoking causes an influx of mononuclear phagocytes and polymorphonuclear leucocytes into the lower airways. These cells have altered oxygen metabolism and release more $\mathrm{H}_{2} \mathrm{O}_{2}$ than phagocytes from nonsmokers. In this study, we intended to determine whether asymptomatic cigarette smokers exhale more $\mathrm{H}_{2} \mathrm{O}_{2}$ than healthy nonsmokers.

The content of $\mathrm{H}_{2} \mathrm{O}_{2}$ in the expired condensate of 27 nonsmokers and 33 cigarette smokers was measured spectrofluorimetrically (homovanillic acid method).

The mean $\mathrm{H}_{2} \mathrm{O}_{2}$ level in the expired breath condensate of all cigarette smokers was about fivefold higher than that found in the whole nonsmoker group $(0.24 \pm 0.32$ versus $0.05 \pm 0.11 \mathrm{nM})$. However, only 16 smokers $(49 \%)$ and 6 nonsmokers $(22 \%)$ had detectable levels of $\mathrm{H}_{2} \mathrm{O}_{2}$ in expired breath that reached values $0.49 \pm 0.28$ and $0.23 \pm 0.10 \mathrm{nM}$, respectively. Although the cigarette smoking status was similar for both male and female smokers, females expired 2.5 fold less $\mathrm{H}_{2} \mathrm{O}_{2}$ than males $(0.15 \pm 0.24(n=21)$ versus $0.38 \pm 0.39(n=12) n M$. No correlation was found between expired $\mathrm{H}_{2} \mathrm{O}_{2}$ levels and cigarette smoking status expressed as the daily cigarette consumption, cumulative cigarette consumption and urinary cotinine concentration.

It is suggested that in some smokers, expressed $\mathrm{H}_{2} \mathrm{O}_{2}$ can be a noninvasive marker of oxidant overload in the lower airways related to cigarette smoking.

Eur Respir J., 1996, 9, 652-657.
Dept of Pneumology and Allergology, Medical University of Lodz, Lodz, Poland.

Correspondence: D. Nowak

Dept of Pneumology and Allergology

Medical University of Lodz

Kopcinskiego st 22

90-153 Lodz

Poland

Keywords: Breath condensate

cigarette smoking

cotinine

expired breath

hydrogen peroxide

Received: April 121995

Accepted after revision December 151995

BS is the recipient of a Polish Government Scholarship for Iranian Students.
Cigarette smoking is the major risk factor in the epidemiology of lung cancer and pulmonary emphysema [1-3]. One of several potential links between cigarette smoking and the development of these diseases is the overburden of lower airways with oxidants and free radicals $[1,4]$. Free radicals and oxidants may cause an elastase-antielastase imbalance in the lower airways [2, $3]$, and induce deoxyribonucleic acid (DNA) damage in epithelial cells $[5,6]$, that may lead to proteolytic lung injury and carcinogenesis. The increased exposure of smoker's lung tissue to oxidants may result from the presence of large amounts of free radicals and oxidants in cigarette smoke. Cigarette smoke contains about $5 \times 10^{14}$ radicals per puff [7], and in aqueous solution it can generate hydrogen peroxide $\left(\mathrm{H}_{2} \mathrm{O}_{2}\right)$ and superoxide radicals [8].

Another, perhaps more important, source of oxidants in the respiratory tract of cigarette smokers is activated phagocytes. Cigarette smoke causes enhanced recruitment of mononuclear phagocytes and polymorphonuclear leucocytes to the lower airways [9-11]. These cells have altered oxygen metabolism and release more $\mathrm{H}_{2} \mathrm{O}_{2}$ and other reactive oxygen species than phagocytes from nonsmokers [12-14]. These data, as a whole, suggest that high concentrations of $\mathrm{H}_{2} \mathrm{O}_{2}$ can occur in the alveolar lining fluid of cigarette smokers. $\mathrm{H}_{2} \mathrm{O}_{2}$ itself is toxic to the cells and plays a central role in the formation of even more toxic reactive oxygen species, hydroxyl radicals and hypochloride anions that can induce severe lung injury $[1,3,4]$. Oxidants, including $\mathrm{H}_{2} \mathrm{O}_{2}$, can diffuse into the blood stream and those not decomposed by anti-oxidant enzymes may be responsible for increased chemiluminescence of smoker's plasma [15], and oxidative damage to circulating $\alpha_{1}$-proteinase inhibitor $[3,16]$.

Some of the $\mathrm{H}_{2} \mathrm{O}_{2}$ can also evaporate from the alveolar lining fluid and could be excreted with the expiratory air of cigarette smokers. It is possible that an elevated content of $\mathrm{H}_{2} \mathrm{O}_{2}$ in expired breath may serve as an indirect marker of free radical-mediated processes, and reflect harmful oxidant overload in the lower airways related to cigarette smoking. In this study, therefore, we wanted to determine whether asymptomatic cigarette smokers exhale more $\mathrm{H}_{2} \mathrm{O}_{2}$ than healthy nonsmokers. By using the spectrofluorimetric method of $\mathrm{H}_{2} \mathrm{O}_{2}$ determination, we found that cigarette smokers had a fivefold higher mean expired breath $\mathrm{H}_{2} \mathrm{O}_{2}$ concentration than nonsmokers, and that male smokers exhaled more $\mathrm{H}_{2} \mathrm{O}_{2}$ than female smokers.

\section{Material and methods}

\section{Reagents}

Cotinine, peroxidase from horseradish type II (HRP, $200 \mathrm{U} \cdot \mathrm{mg}^{-1}$ solid), 4-hydroxy-3-methoxy-phenylacetic 
acid (homovanillic acid), and Triton X-100 were from Sigma Chemical Co. (St. Louis, MO, USA). Chloramine-T, glycine, ethylenediamine tetra-acetic acid (EDTA), barbituric acid, acetone, sodium metabisulphite, $\mathrm{KCN}$, phosphate-buffered saline (PBS) $\mathrm{pH} 7.4$, and $30 \% \mathrm{H}_{2} \mathrm{O}_{2}$ solution were purchased from POCH (Gliwice, Poland). Thirty percent $\mathrm{H}_{2} \mathrm{O}_{2}$ solution was diluted 100 fold with $\mathrm{PBS}$ and stored at $4{ }^{\circ} \mathrm{C}$ in the dark. The actual $\mathrm{H}_{2} \mathrm{O}_{2}$ concentration was calculated from its absorbance at $320 \mathrm{~nm}(\mathrm{E}=81$ $\mathrm{cm}^{-1} \cdot \mathrm{M}^{-1}$ ) [17]. Sterile, deionized water (conductivity $0.05 \mu \mathrm{S} \cdot \mathrm{cm}^{-1}$, Milli-Q Plus Water Purification System) was used throughout the study. Aqueous solutions of 1 $\mathrm{M}$ sodium metabisulphite, $0.4 \mathrm{M}$ chloramine- $\mathrm{T}$, and 1 $\mathrm{U} \cdot \mathrm{mL}^{-1} \mathrm{HRP}$, with addition of $400 \mu \mathrm{M}$ homovanillic acid, were prepared freshly before the assay. All other solutions were stored at $4^{\circ} \mathrm{C}$ for not more than for 14 days.

\section{Study population}

Sixty healthy subjects, members of our medical staff who had not suffered from any infectious diseases for the previous 4 months, participated in the study. Twenty seven were nonsmokers (mean age $36 \pm 3$ yrs, 14 males and 13 females) and 33 were smokers (mean age $39 \pm 10$ yrs, 12 males and 21 women). The mean daily cigarette consumption was $15 \pm 7$, and the mean cumulative cigarette consumption was $13.6 \pm 9.6$ pack-years. The mean age of male smokers, female smokers, male nonsmokers and female nonsmokers was $37 \pm 11,40 \pm 9,36 \pm 4$ and $35 \pm 3$ yrs, respectively. The mean daily cigarette consumption was $15 \pm 7$ in males and $15 \pm 7$ in females. The cumulative cigarette consumption for male smokers and female smokers was $12 \pm 10$ and $14 \pm 9$ pack-yrs, respectively. None of the women were pregnant or took contraceptives. All subjects were free of medication and routine physical examination showed nothing abnormal. The study had the approval of the local Ethics Committee, and informed consent was obtained.

\section{Collection of air condensate}

The expired breath condensate was collected in a tube installed in a polystyrene foam container filled with ice and salt. The $230 \mathrm{~cm}$ long polypropylene tube (internal diameter $10 \mathrm{~mm}$ ) was incubated overnight in $3 \% \mathrm{H}_{2} \mathrm{O}_{2}$ solution, to saturate all groups that can react with $\mathrm{H}_{2} \mathrm{O}_{2}$. After two washes, the tube was submerged in distilled water for $24 \mathrm{~h}$ (with three changes of water). It was then dried under a flow of nitrogen gas and installed in the polystyrene foam container. The collecting part (170 $\mathrm{cm}$ length) of the tube was covered with ice and salt. The temperature in the tube vicinity, measured with thermocouple, ranged -6 to $0^{\circ} \mathrm{C}$ and allowed condensation of all $\mathrm{H}_{2} \mathrm{O}_{2}$ present in the expiratory air [18].

Patients were asked to breathe out spontaneously through a mouthpiece with a saliva-trap connected to the tube and to breathe in with the mouthpiece removed, for 20 $\min$. The respiratory rate ranged $15-18$ breaths $\cdot \mathrm{min}^{-1}$. Each subject wore a noseclip and rinsed their mouth with distilled water just before and at 7 and 14 min of collection, to reduce the evaporation of $\mathrm{H}_{2} \mathrm{O}_{2}$ from saliva [18] and nasal spaces. At the end of collection, the tube was carefully removed from the container and $2-5 \mathrm{~mL}$ aliquots of condensate were transferred to Eppendorf tubes. One sample was used for determination of condensate osmolality using an osmometer $800 \mathrm{cI}$, Trident (Warsaw, Poland) and the rest was stored at $-80^{\circ} \mathrm{C}$ for not more than 7 days until $\mathrm{H}_{2} \mathrm{O}_{2}$ measurement.

Preliminary experiments with three different samples of breath condensate and $10^{-7} \mathrm{M} \mathrm{H}_{2} \mathrm{O}_{2}$ solution showed that, under these conditions, the $\mathrm{H}_{2} \mathrm{O}_{2}$ concentration was stable for at least 14 days of storage. Similarly, $5 \mathrm{nM}$ $\mathrm{H}_{2} \mathrm{O}_{2}$ solution poured into the collection device and incubated for $20 \mathrm{~min}$ at $0^{\circ} \mathrm{C}$ revealed no significant change of ability to oxidize homovanillic acid.

The fluorescence at $420 \mathrm{~nm}$ expressed in arbitrary units was $142 \pm 4$ and $145 \pm 2(n=3)$ for samples before and after incubation, respectively. The tube was washed three times with distilled water, dried under a flow of nitrogen gas and again fitted into the container. All collections were performed between 9 and 11 a.m. and subjects refrained from cigarette smoking during the $12 \mathrm{~h}$ preceding the visit. On the day of the visit, all smoking volunteers were asked whether they had stopped smoking $12 \mathrm{~h}$ before the visit. Six individuals failed to refrain from smoking. In this case, the breath condensate and urine samples were not collected and the visit was rescheduled within 1-7 days.

\section{Measurement of hydrogen peroxide}

The content of $\mathrm{H}_{2} \mathrm{O}_{2}$ in expired breath condensate was determined according to the method of RuCH et al. [19]. Briefly, $10 \mu \mathrm{L}$ of expired breath condensate was mixed with $90 \mu \mathrm{L}$ PBS and $100 \mu \mathrm{L}$ of a solution of HRP $\left(1 \mathrm{U} \cdot \mathrm{mL}^{-1}\right)$ containing $400 \mu \mathrm{M}$ homovanillic acid and was incubated for $60 \mathrm{~min}$ at $37^{\circ} \mathrm{C}$. Afterwards, the sample was mixed with $300 \mu \mathrm{L}$ PBS and $125 \mu \mathrm{L} 0.1 \mathrm{M}$ glycine$\mathrm{NaOH}$ buffer ( $\mathrm{pH} 12.0$ ) with addition of $25 \mathrm{mM}$ EDTA and was transferred into microcuvettes (PE 5200-4339). The homovanillic acid oxidation product as a measure of the amount of $\mathrm{H}_{2} \mathrm{O}_{2}$ was determined spectrofluorimetrically using a Perkin Elmer Luminescence Spectrometer LS-50 (Norwalk, CT, USA) operating in the read mode. Slit widths were set at $10 \mathrm{~nm}$ both for emission and excitation and the integrate time was $0.1 \mathrm{~s}$. Excitation was at $312 \mathrm{~nm}$ and emission was measured at $420 \mathrm{~nm}$.

Readings were converted into $\mathrm{nM}$ using the regression equation $\mathrm{Y}=0.0375 \mathrm{X}-0.3221$ (where $\mathrm{Y}=$ nanomoles of $\mathrm{H}_{2} \mathrm{O}_{2}$ per litre of expired breath condensate; and $\mathrm{X}=$ intensity of emission at $420 \mathrm{~nm}$ expressed in arbitrary units) obtained from three series of calibration experiments with 19 increasing ( 0.01 to $10 \mathrm{nM}) \mathrm{H}_{2} \mathrm{O}_{2}$ concentrations. The confidence level was $95 \%$ and p-value was less than 0.03 and 0.0001 for constant and regression coefficient, respectively. The linear least squares estimation was used for calculation of the regression equation. The lower limit of $\mathrm{H}_{2} \mathrm{O}_{2}$ detection was $0.1 \mathrm{nM}$.

\section{Cotinine determination}

A $5 \mathrm{~mL}$ morning sample of urine was collected on the same day as the breath condensate, and was stored at 
$-80^{\circ} \mathrm{C}$ until determination of the cotinine concentration using a modified direct barbituric acid (DBA) method [20]. Urine gives absorbance at $490 \mathrm{~nm}$ due to its natural yellow colour. Therefore, we corrected the results of cotinine determination by subtraction of appropriate absorbances given by water dilutions of urine. Thus, our cotinine readings were about 10 fold lower than those originally described by BARLOw et al. [20]. However, they were similar to those obtained using the radioimmunoassay method of cotinine determination [20, 21].

Briefly, $0.8 \mathrm{~mL}$ of urine was mixed with $0.4 \mathrm{~mL} 4 \mathrm{M}$ sodium acetate buffer ( $\mathrm{pH} 4.7), 160 \mu \mathrm{L} 1.5 \mathrm{M} \mathrm{KCN}, 160$ $\mu \mathrm{L} 0.4 \mathrm{M}$ chloramine-T and $0.8 \mathrm{~mL} 78 \mathrm{mM}$ barbituric acid in acetone:water $(50 \% \mathrm{v} / \mathrm{v})$. After $15 \mathrm{~min}$ incubation at room temperature, the reaction was stopped by addition of $160 \mu \mathrm{L} 1 \mathrm{M}$ sodium metabisulphite and then the absorbance of the reaction mixture was measured at 490 $\mathrm{nm}$ on Ultrospec III (Pharmacic LKB) against a blank containing water instead of urine. Results were corrected by subtraction of absorbance given by $0.8 \mathrm{~mL}$ urine diluted with $1.68 \mathrm{~mL}$ water alone. The urinary cotinine concentration was calculated using the regression equation: $\mathrm{Y}=8335 \mathrm{X}-345$ (where $\mathrm{Y}=\mu$ moles of cotinine per litre of urine; and $X=$ corrected absorbance at 490 $\mathrm{nm}$ ) obtained from three series of calibration experiments with 15 increasing $(0.1$ to $250 \mu \mathrm{M})$ cotinine concentrations. The confidence level was $95 \%$ and p-value was less than 0.0001 both for constant and regression coefficient. The lower limit of cotinine detection was $0.5 \mu \mathrm{M}$.

\section{Statistical analysis}

Data from subjects are expressed as the mean \pm sD. For readings that gave results below the method sensitivities both the urinary cotinine concentration and $\mathrm{H}_{2} \mathrm{O}_{2}$ concentration in expired breath condensate were assumed as $0 \mu \mathrm{M}$ and $0 \mathrm{nM}$, respectively. The differences between results found in groups of smokers and nonsmokers were determined by analysis of variance (ANOVA). A p-value of less than 0.05 was considered to be significant. Pearson correlation was utilized to determine the relationships between measured variables. All calculations were performed using Microsoft Excel version 5.0 software.

\section{Results}

Preliminary experiments with repeated condensate collection from four volunteers (two smokers and two nonsmokers) revealed that $\mathrm{H}_{2} \mathrm{O}_{2}$ concentration in expired breath was stable during 4 days of observation (table 1). Analysis of breath condensates collected on consecutive days from one subject with no detectable $\mathrm{H}_{2} \mathrm{O}_{2}$ in the first measurement gave the same results independently of the day of collection. Moreover, the concentration of $\mathrm{H}_{2} \mathrm{O}_{2}$ was similar in three breath condensates collected consecutively at the same day with $30 \mathrm{~min}$ time intervals. The mean variation coefficient for readings obtained with three condensates collected on the same day and all condensates obtained from volunteers except those with no detectable $\mathrm{H}_{2} \mathrm{O}_{2}$ was $0.09 \pm 0.03$ and $0.08 \pm 0.02$, respectively. When subjects did not wash their mouths
Table 1. $-\mathrm{H}_{2} \mathrm{O}_{2}$ concentration of expired breath condensate collected for four consecutive days from four volunteers

\begin{tabular}{|c|c|c|c|c|}
\hline \multirow{2}{*}{$\begin{array}{l}\text { Day of } \\
\text { collection }\end{array}$} & \multicolumn{4}{|c|}{ Subject } \\
\hline & $1(\mathrm{NS})$ & $2(\mathrm{NS})$ & $3(\mathrm{~S})$ & $4(\mathrm{~S})$ \\
\hline \multirow[t]{3}{*}{1} & 0 & 0.18 & 0.28 & 0.21 \\
\hline & 0 & 0.18 & 0.33 & 0.18 \\
\hline & 0 & 0.16 & 0.26 & 0.19 \\
\hline 2 & 0 & 0.17 & 0.26 & 0.22 \\
\hline 3 & 0 & 0.15 & 0.29 & 0.20 \\
\hline 4 & 0 & 0.18 & 0.30 & - \\
\hline No noseclip & 0 & 0.20 & 0.35 & - \\
\hline No mouthwash & 0.18 & 0.21 & 0.41 & - \\
\hline $\begin{array}{l}15 \mathrm{mM} \mathrm{H}_{2} \mathrm{O}_{2} \\
\text { mouthwash }\end{array}$ & 0.52 & 0.38 & 0.47 & - \\
\hline
\end{tabular}

Volunteers ( 2 smokers and 2 nonsmokers) were asked to breathe out spontaneously through a mouthpiece with a saliva-trap connected to the tube and to breathe in with the mouthpiece removed from the mouth, for $20 \mathrm{~min}$. They wore a noseclip and rinsed the mouth with distilled water just before and at 7 and $14 \mathrm{~min}$ of the condensate collection. On the 1st and 4th day, 3 and 4 separate collections were performed, respectively on day 4 different conditions were tested. The interval between collections was $30 \mathrm{~min}$. NS: nonsmoker; S: smoker.

with distilled water just before and during condensate collection, the $\mathrm{H}_{2} \mathrm{O}_{2}$ level increased by about $0.07 \pm 0.04$ nM. Similarly, rinsing the mouth with $15 \mathrm{mM} \mathrm{H}_{2} \mathrm{O}_{2}$ resulted in a rise of condensate $\mathrm{H}_{2} \mathrm{O}_{2}$ level by $0.26 \pm 0.14$ $\mathrm{nM}$. Removal of the noseclip also increased the concentration of $\mathrm{H}_{2} \mathrm{O}_{2}$ in the condensate. Therefore, the evaluation of the influence of cigarette smoking on the content of $\mathrm{H}_{2} \mathrm{O}_{2}$ in expired breath was based on the analysis of one condensate collected whilst using a noseclip and with rinsing of the mouth with distilled water.

Only 6 nonsmoking subjects $(22 \%)$ revealed a detectable content of $\mathrm{H}_{2} \mathrm{O}_{2}$ in expired breath condensate. In 21 nonsmokers $(78 \%)$ the $\mathrm{H}_{2} \mathrm{O}_{2}$ level was below the method sensitivity $(0.1 \mathrm{nM})$ and was assumed to be 0 nM. Thus, the mean $\mathrm{H}_{2} \mathrm{O}_{2}$ concentration in expired breath condensate calculated for the whole group of 27 healthy nonsmokers was $0.05 \pm 0.11 \mathrm{nM}$ (fig. 1). The $\mathrm{H}_{2} \mathrm{O}_{2}$ level in the expired breath of 33 cigarette smokers was about fivefold higher $(\mathrm{p}<0.01)$ than that observed in the whole nonsmoker group, and reached $0.24 \pm 0.32 \mathrm{nM}(\mathrm{n}=33)$. In 17 smokers $(51 \%)$, no detectable $\mathrm{H}_{2} \mathrm{O}_{2}$ concentrations were noted. The mean expired breath $\mathrm{H}_{2} \mathrm{O}_{2}$ concentration obtained for smokers with detectable levels of $\mathrm{H}_{2} \mathrm{O}_{2}$ was $0.49 \pm 0.28 \mathrm{nM}(\mathrm{n}=16)$ and was 2.1 fold higher than that found in the nonsmokers with positive $\mathrm{H}_{2} \mathrm{O}_{2}$ assays $(0.23 \pm 0.10 \mathrm{nM}, \mathrm{n}=6)$. Male smokers had a higher mean concentration of $\mathrm{H}_{2} \mathrm{O}_{2}$ than female smokers $(0.38 \pm 0.39$ versus $0.15 \pm 0.24 \mathrm{nM} ; \mathrm{p}<0.01)$.

The mean urinary cotinine concentration in cigarette smokers was 5.1 fold higher than that found in nonsmokers $(3.6 \pm 2.9$ versus $0.7 \pm 1.8 \mu \mathrm{M} ; \mathrm{p}<0.001)$. Male smokers revealed higher cotinine levels than female smokers $(4.9 \pm 3.2$ versus $2.9 \pm 2.6 \mu \mathrm{m} ; \mathrm{p}<0.05)$. Six cigarette smokers $(18 \%)$ had no detectable cotinine in urine, whilst in four nonsmokers $(15 \%)$ the urinary cotinine concentration was above the method sensitivity. This 


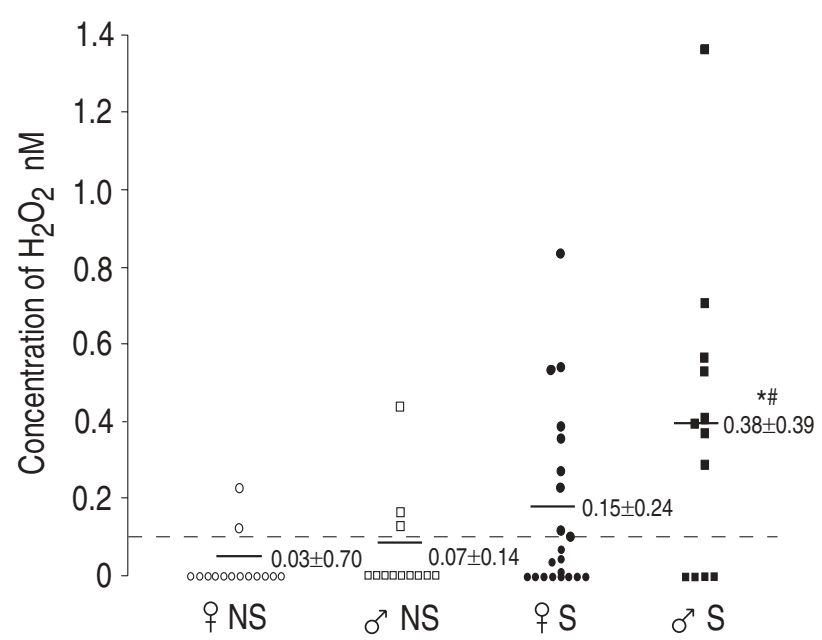

Fig. 1. - $\mathrm{H}_{2} \mathrm{O}_{2}$ concentration in expired breath condensate of healthy female nonsmokers (○), male nonsmokers $(\sqsupset)$, female smokers $(\bullet)$ and male smokers (ם). Individual results below the sensitivity of $\mathrm{H}_{2} \mathrm{O}_{2}$ method determination $(0.1 \mathrm{nM}$, dashed horizontal line) were assumed to be $0 \mathrm{nM}$. *: $\mathrm{p}<0.01$, significantly different from female smokers; $\#: \mathrm{p}<0.01$, significantly different from male nonsmokers. The mean $\mathrm{H}_{2} \mathrm{O}_{2}$ level in breath condensate of all cigarette smokers (male and female) was higher than that found in nonsmokers $(0.24 \pm 0.32$ versus $0.05 \pm 0.11 \mathrm{nM} ; \mathrm{p}<0.01)$.

may result from random exposure of nonsmokers to sidestream cigarette smoke and the slower clearance of cotinine in nonsmokers than smokers $[22,23]$. On the other hand, cessation of smoking for $12 \mathrm{~h}$ before urine collection may be responsible for the negative cotinine assays in some smokers.

The mean osmolality of expired breath condensate was similar both for smokers and nonsmokers $(5.9 \pm 2.1 \mathrm{ver}$ sus $\left.5.4 \pm 2.5 \mathrm{mOsm} \cdot \mathrm{kg}^{-1} \mathrm{H}_{2} \mathrm{O}\right)$. There were also no significant differences between condensate osmolality of male smokers $(6.1 \pm 2.2)$, female smokers $(5.8 \pm 2.0)$, male nonsmokers $(5.1 \pm 2.6)$ and female nonsmokers $(5.7 \pm 2.3$ $\left.\mathrm{mOsm} \cdot \mathrm{kg}^{-1} \mathrm{H}_{2} \mathrm{O}\right)$. Since the mean osmolality of saliva samples collected from all volunteers involved in the study was $95 \pm 12 \mathrm{mOsm} \cdot \mathrm{kg}^{-1} \mathrm{H}_{2} \mathrm{O}$, it indicates that there was no significant saliva contamination in breath condensates of any group analysed. The relatively high osmolality of breath condensate compared to $\mathrm{H}_{2} \mathrm{O}_{2}$ levels suggests the presence of other substances. Breath contains at least several dozen compounds that are present at nanogram per litre quantities [24]. The mean $\mathrm{pH}$ (6.83 \pm $0.17)$, carbon dioxide tension $\left(\mathrm{PCO}_{2}\right)(1.4 \pm 0.12 \mathrm{kPa})$, and $\mathrm{HCO}_{3}{ }^{-}$concentration $(1.7 \pm 0.2 \mathrm{mM})(\mathrm{n}=6)$ in freshly collected breath condensate suggest that dissolved $\mathrm{CO}_{2}$ and $\mathrm{HCO}_{3}^{-}$are mainly responsible for its osmolality.

No correlation was found between the osmolality of expired breath condensate and the present and cumulative cigarette consumption $(\mathrm{r}=-0.19, \mathrm{p}<0.3$; and $\mathrm{r}=-0.13$, $\mathrm{p}<0.5$ ). There were also no significant correlations between expired $\mathrm{H}_{2} \mathrm{O}_{2}$ levels and urinary cotinine concentration $\left(\mathrm{r}=0.18, \mathrm{p}<0.3\right.$ ) (fig. 2a), expired $\mathrm{H}_{2} \mathrm{O}_{2}$ levels and current cigarette consumption $(\mathrm{r}=0.2, \mathrm{p}<0.4)$ (fig. $2 \mathrm{~b}$ ), expired $\mathrm{H}_{2} \mathrm{O}_{2}$ levels and cumulative cigarette consumption $(\mathrm{r}=0.16, \mathrm{p}<0.4)$ and expired $\mathrm{H}_{2} \mathrm{O}_{2}$ levels and condensate osmolality $(\mathrm{r}=0.03, \mathrm{p}<0.9)$.

\section{Discussion}

We found that asymptomatic cigarette smokers had higher $\mathrm{H}_{2} \mathrm{O}_{2}$ levels in expired breath condensate than nonsmoking subjects. Since the smokers refrained from cigarette smoking for $12 \mathrm{~h}$ prior to the study, one might conclude that the main source of expired $\mathrm{H}_{2} \mathrm{O}_{2}$ are activated phagocytes. During this period, $\mathrm{H}_{2} \mathrm{O}_{2}$ generated directly from cigarette smoked should be removed by antioxidants present in the alveolar lining fluid [25]. Cigarette smokers have an increased number of alveolar macrophages and polymorphonuclear leucocytes in the lower airways [9-11]. These cells release more $\mathrm{H}_{2} \mathrm{O}_{2}$ than those of nonsmokers $[12,14,26]$. Alveolar macrophages from cigarette smokers release 3-8 nmoles of $\mathrm{H}_{2} \mathrm{O}_{2} \cdot \mathrm{h}^{-1} \cdot 10^{-6}$ cells in vitro [26]. CANTIN et al. [25] calculated the average potential $\mathrm{H}_{2} \mathrm{O}_{2}$ burden in alveolar a)

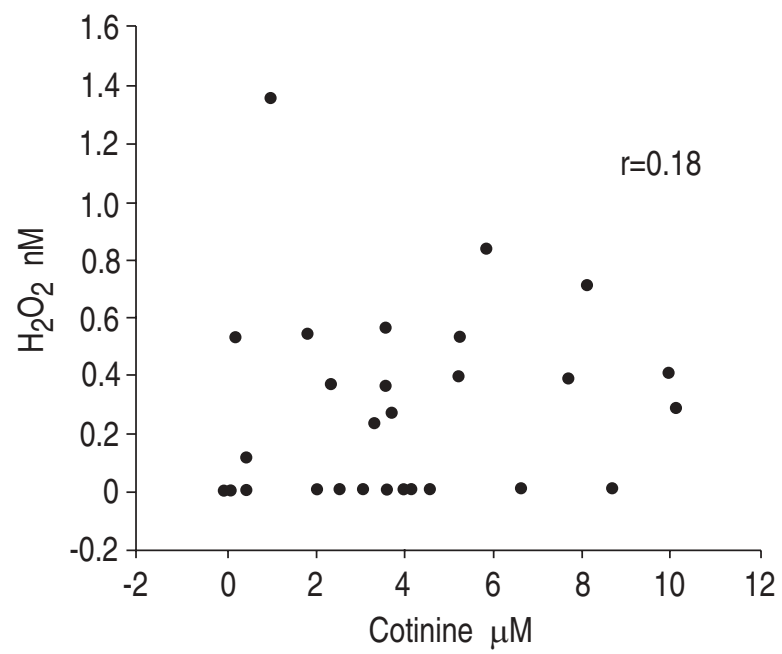

b)

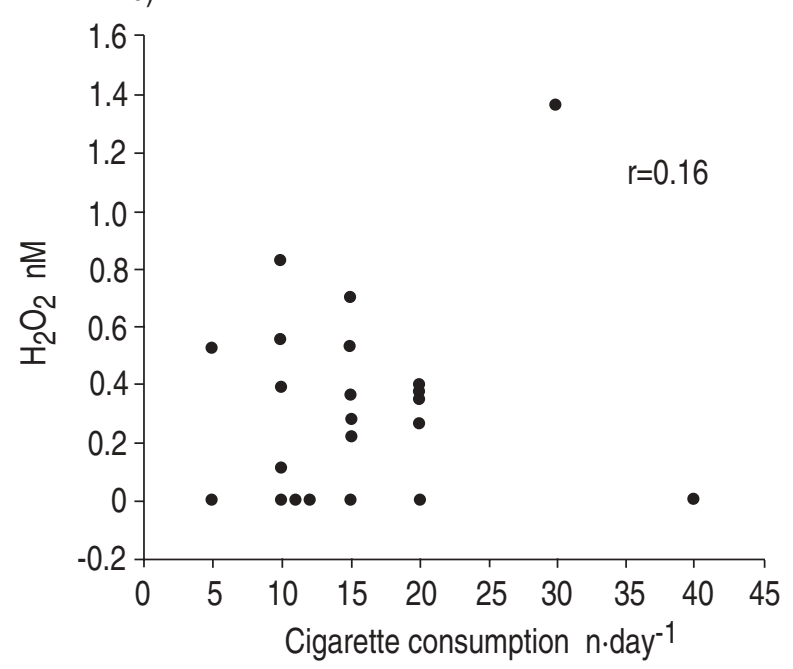

Fig. 2. - No correlations were found in cigarette smokers between expired breath $\mathrm{H}_{2} \mathrm{O}_{2}$ concentrations and: a) urinary cotinine concentration; and b) current cigarette consumption. 
lining fluid of cigarette smokers as $80 \mathrm{nmoles} \cdot \mathrm{mL}^{-1} \cdot \mathrm{h}^{-1}$. Assuming that the volume of alveolar lining fluid is about $3 \mathrm{~mL}$ [27], the total $\mathrm{H}_{2} \mathrm{O}_{2}$ generation can reach 240 nmoles $\cdot \mathrm{h}^{-1}$. The average volume of condensate collected during $20 \mathrm{~min}$ was $3.5 \mathrm{~mL}$. Thus, our smokers with detectable $\mathrm{H}_{2} \mathrm{O}_{2}$ exhaled about 5 picomoles of $\mathrm{H}_{2} \mathrm{O}_{2} \cdot \mathrm{h}^{-1}$. This amount is about $5 \times 10^{4}$ times lower than the $\mathrm{H}_{2} \mathrm{O}_{2}$ generation in alveolar lining fluid estimated above.

The great difference between $\mathrm{H}_{2} \mathrm{O}_{2}$ generation and exhalation (related to its evaporation) may result from the presence of antioxidants in the lower airways. Catalase is an important component of antioxidant defence in the alveolar lining fluid. However, it scavenges high concentrations of $\mathrm{H}_{2} \mathrm{O}_{2}$ most efficiently [25]. Thus, part of $\mathrm{H}_{2} \mathrm{O}_{2}$ (representing low concentrations) would not be metabolized and is detected in breath condensate. On the other hand, in 17 smokers, we were unable to detect any $\mathrm{H}_{2} \mathrm{O}_{2}$ in condensate. This may result from increased permeability of airways in cigarette smokers, that allows diffusion of serum antioxidant proteins (e.g. ceruloplasmin) into the alveolar lining fluid, thus increasing anti- $\mathrm{H}_{2} \mathrm{O}_{2}$ protection in these subjects [28]. Moreover catalase activity in the alveolar lining fluid has been shown to be increased in cigarette smokers [29]. The presence of relatively high concentrations of reduced glutathione, that with glutathione peroxidase forms an efficient system removing low concentrations of $\mathrm{H}_{2} \mathrm{O}_{2}$, could also be responsible for this observation. However, some reports question the importance of reduced glutathione in the pulmonary antioxidant defence [30, 31]. Removal of $\mathrm{H}_{2} \mathrm{O}_{2}$ by antioxidant enzymes would explain the lack of correlation between measurements of exposure to cigarette smoke (urinary cotinine) and the level of $\mathrm{H}_{2} \mathrm{O}_{2}$ in breath condensate.

Smokers with increased $\mathrm{H}_{2} \mathrm{O}_{2}$ in expired breath may represent those in whom oxidant load overcomes the capacity of the antioxidant protection in the lower airways. However, some of the nonsmokers also had $\mathrm{H}_{2} \mathrm{O}_{2}$ in expired breath condensate, which is in agreement with a previous study showing the peroxide-dependent spontaneous chemiluminescence of human breath [24]. In addition, some healthy volunteers excreted micromolar concentrations of $\mathrm{H}_{2} \mathrm{O}_{2}$ in urine [32].

The lack of difference between photon counts obtained from breath collected before and $5 \mathrm{~min}$ after smoking a cigarette [24], supports our hypothesis that the source of exhaled $\mathrm{H}_{2} \mathrm{O}_{2}$ is phagocytes and not cigarette smoke itself. $\mathrm{H}_{2} \mathrm{O}_{2}$ present in the expired breath condensate can also originate from lung microsomes and mitochondria [18, 24]. However, it is not known whether cigarette smoke can enhance $\mathrm{H}_{2} \mathrm{O}_{2}$ generation from these sources.

SZNAJER et al. [18] did not find any $\mathrm{H}_{2} \mathrm{O}_{2}$ in condensate collected from mechanically-ventilated patients undergoing nonthoracic surgery. Their use of a less sensitive method for $\mathrm{H}_{2} \mathrm{O}_{2}$ determination (sensitivity about $1 \mu \mathrm{M}$ $\mathrm{H}_{2} \mathrm{O}_{2}$ ) could explain these negative results. On the other hand, when they analysed breath condensates collected from healthy volunteers, without the use of a saliva-trap, noseclip and rinsing of the mouth with distilled water before and during collection, the $\mathrm{H}_{2} \mathrm{O}_{2}$ levels were about 1000 fold higher than those in our nonsmoking subjects. These differences may result from the contamination of breath condensates with saliva that contains high amounts of $\mathrm{H}_{2} \mathrm{O}_{2}$ [18].
This explanation would be consistent with the study by Dohlman et al. [33], showing that the use of a collection device provided with a saliva-trap resulted in a 10 fold reduction of condensate $\mathrm{H}_{2} \mathrm{O}_{2}$ levels in comparison to the results of SzNAJDER et al. [18]. In addition, they found that some healthy volunteers did not have any $\mathrm{H}_{2} \mathrm{O}_{2}$ in breath condensate [33]. These subjects, like the volunteers involved in the study by SZNAJDER et al. [18], did not use the noseclip or rinse their mouths. This may explain the lower rate of negative $\mathrm{H}_{2} \mathrm{O}_{2}$ readings than that reported here.

These differences could also result from the loss of breath condensate $\mathrm{H}_{2} \mathrm{O}_{2}$ in our collection device and during 7 days of storage. However, our preliminary experiments with standard $\mathrm{H}_{2} \mathrm{O}_{2}$ solutions and breath condensates showed that this is unlikely. In addition, bubbling of one breath through $10 \mathrm{~mL}$ aliquots or peroxide assay mixture gave similar $\mathrm{H}_{2} \mathrm{O}_{2}$ concentrations to those in our study [24]. As was mentioned above, the generation of $\mathrm{H}_{2} \mathrm{O}_{2}$ from nasal spaces can influence the $\mathrm{H}_{2} \mathrm{O}_{2}$ readings in breath condensate. $\mathrm{H}_{2} \mathrm{O}_{2}$ evaporated from the nasal spaces could be inspired into the airways and then expired into the collection device and undergo condensation. However, the contribution of $\mathrm{H}_{2} \mathrm{O}_{2}$ from the nasal spaces seems to be low, according to our preliminary experiments (table 1).

The second finding of our study was that male smokers had higher concentrations of $\mathrm{H}_{2} \mathrm{O}_{2}$ in breath condensate than female smokers. This is difficult to explain in view of the stimulatory effect of progesterone on polymorphonuclear leucocyte (PMNL) chemotaxis and respiratory burst $[34,35]$. On the other hand, there were no differences between $\mathrm{H}_{2} \mathrm{O}_{2}$ release by alveolar macrophages isolated from male and female smokers [26]. Female smokers had higher serum ceruloplasmin concentrations than male smokers [36]. This protein is present in the alveolar lining fluid and can decompose $\mathrm{H}_{2} \mathrm{O}_{2}$ $[25,37]$. Perhaps, higher concentrations of ceruloplasmin and catalase activity in the airways of the females may be responsible for the lower content of $\mathrm{H}_{2} \mathrm{O}_{2}$ in their exhaled air.

Previous reports have shown that patients with adult respiratory distress syndrome, pneumonia or bronchial asthma exhale increased amounts of $\mathrm{H}_{2} \mathrm{O}_{2}$ in expired breath $[18,33,38]$. Although, these diseases are characterized by a large influx of activated phagocytes into the lower airways, some of the patient samples did not contain any $\mathrm{H}_{2} \mathrm{O}_{2}[33,38]$. Cigarette smoking causes a lower inflammatory response in the lung tissue than the above-mentioned diseases. In addition, it needs many years to develop severe lung injury. Therefore, the higher rate of negative $\mathrm{H}_{2} \mathrm{O}_{2}$ assays in breath condensate of cigarette smokers seems to be a natural consequence of this fact. It is possible that the number of positive assays would be higher in a smoking population with symptoms of obstructive lung disease: however, this requires further study. Nevertheless, the fivefold higher mean breath condensation $\mathrm{H}_{2} \mathrm{O}_{2}$ level and twofold higher frequency of positive $\mathrm{H}_{2} \mathrm{O}_{2}$ readings in asymptomatic cigarette smokers than in nonsmokers show that spectrofluorimetric measurement of $\mathrm{H}_{2} \mathrm{O}_{2}$ in expired breath could be a sensitive, noninvasive method for detection of enhanced generation of reactive oxygen species in the lower airways related to cigarette smoking. 


\section{References}

1. Pryor WA. Oxyradicals and related species: their formation, lifetimes and reactions. Ann Rev Physiol 1986; 48: 657-667.

2. Stockley RA. Alpha ${ }_{1}$-antitrypsin and the pathogenesis of emphysema. Lung 1987; 165: 61-77.

3. Carp H, Miller F, Hoidal JR, Janoff A. Potential mechanism of emphysema: $\alpha_{1}$-proteinase inhibitor recovered from lungs of cigarette smokers contains oxidized methionine and has decreased elastase inhibitory capacity. Proc Natl Acad Sci 1982; 79: 2041-2045.

4. Janoff A. Elastases and emphysema: current assessment of the protease-antiprotease theory of emphysema. Am Rev Respir Dis 1985; 132: 417-433.

5. Nakayama T, Kaneko M, Kodama M, Nagata C. Cigarette smoke induces DNA single strand-breaks in human cells Nature 1985; 314: 462-464.

6. Jackson JH, Schraufstatter IU, Hyslop PA, et al. Role of oxidants in DNA damage: hydroxyl radical mediates the synergistic DNA damaging effects of asbestos and cigarette smoke. J Clin Invest 1987; 80: 1090-1095.

7. Pryor WA, Prier DG, Church DF. Electron spin resonance study of mainstream and sidestream cigarette smoke: nature of the free radicals in gas-phase smoke and in cigarette tar. Environ Health Perspect 1983; 47: 345-355.

8. Nakayama T, Kodama M, Nagata C. Generation of hydrogen peroxide and superoxide anion radical from cigarette smoke. Gann 1984; 75: 95-98.

9. Hunninghake GW, Crystal RG. Cigarette smoking and lung destruction: accumulation of neutrophils in the lungs of cigarette smokers. Am Rev Respir Dis 1983; 128: 833-836.

10. Hoidal JR, Niewoehner DE. Lung phagocyte recruitment and metabolic alterations induced by cigarette smoke in humans and in hamsters. Am Rev Respir Dis 1982; 126: $548-552$

11. Chang JC, Yoo OH, Lesser M. Cathepsin D activity is increased in alveolar macrophages and bronchoalveolar lavage fluid of smokers. Am Rev Respir Dis 1989; 140: 958-960.

12. Baughman RP, Corser BC, Strohofer S, Hendricks D. Spontaneous hydrogen peroxide release from alveolar macrophages of some cigarette smokers. J Lab Clin Med 1986; 107: 233-237.

13. Hoidal J, Fox RB, LeMarbe PA, Perri R, Repine JE. Altered oxidative metabolic response in vitro of alveolar macrophages from asymptomatic cigarette smokers. Am Rev Respir Dis 1981; 123: 85-89.

14. Ludwig PW, Hoidal JR. Alterations in leukocyte oxidative metabolism in cigarette smokers. Am Rev Respir Dis 1982; 126: 977-980.

15. Yoda B, Goto Y, Sato K, Saeki A, Inaba H. Ultra-weak chemiluminescence of smoker's blood. Arch Environ Health 1985; 40: 148-150.

16. Beatty K, Robertie P, Senior RM, Travis J. Determination of oxidized alpha 1 -proteinase inhibitor in serum. $J \mathrm{Lab}$ Clin Med 1982; 100: 186-192.

17. Homann-Muller JWT, Weening RS, Roos D. Production of hydrogen peroxide by phagocytizing human granulocytes. J Lab Clin Med 1975; 85: 198-207.

18. Sznajder JI, Fraiman A, Hall JB, et al. Increased hydrogen peroxide in the expired breath of patients with acute hypoxemic respiratory failure. Chest 1989; 96: 606-612.

19. Ruch W, Cooper PH, Baggiolini M. Assay of $\mathrm{H}_{2} \mathrm{O}_{2}$ production by macrophages and neutrophils with homovanillic acid and horseradish peroxidase. J Immunol Meth 1983; 63: 347-357.
20. Barlow RD, Stone RB, Wald NJ, Puhakainen EVJ. The direct barbituric acid assay for nicotine metabolites in urine: a simple colorimetric test for the routine assessment of smoking status and cigarette smoke intake. Clin Chim Acta 1987; 165: 45-52.

21. Wald NJ, Boreham J, Bailey A, Ritchie C, Haddow JE, Knight G. Urinary cotinine as marker of breathing other people's tobacco smoke. Lancet 1984; i: 230-231.

22. Benowitz NL, Kuyt F, Jacop P, Jones RT, Osman AL. Cotinine dispositions and effects. Clin Pharmacol Ther 1983; 30: 139-142.

23. Feyerabend C, Higenbottam T, Russell M. Nicotine concentrations in urine and saliva of smokers and nonsmokers. Br Med J 1982; 284: 1002-1004.

24. Williams MD, Chance B. Spontaneous chemiluminescence of human breath. J Biol Chem 1983; 258: 36283631.

25. Cantin AM, Fells GA, Hubbard RC, Crystal RG. Antioxidant macromolecules in the epithelial lining fluid of the normal human lower respiratory tract. J Clin Invest 1990; 86: 962-971.

26. Greening AP, Lowrie DB. Extracellular release of hydrogen peroxide by human alveolar macrophages: the relationship to cigarette smoking and lower respiratory tract infections. Clin Sci 1983; 65: 661-664.

27. Blue M, Janoff A. Possible mechanisms of emphysema in cigarette smokers: release of elastase from human polymorphonuclear leukocytes by cigarette smoke condensate in vitro. Am Rev Respir Dis 1978; 117: 317-325.

28. Hogg JC. The effect of smoking on airway permeability. Chest 1983; 83: 1-2.

29. Greening AP, Downing I, Wood NE, Flenley DC. Pulmonary antioxidants: catalase activity but not ceruloplasmin is increased in smokers. Am Rev Respir Dis 1985; 131: A385.

30. Ospital JJ, Kasuyama RS, Tierney DF. Poor correlation between oxygen toxicity and activity of glutathione peroxidase. Exp Lung Res 1983; 5: 193-199.

31. Smith LJ, Anderson J. Oxygen-induced lung damage: relationship to lung mitochondrial glutathione levels. Am Rev Respir Dis 1992; 146: 1452-1457.

32. Varma SD, Devamanoharan PS. Excretion of peroxide in human urine. Free Rad Res Commun 1990; 8: 73-78.

33. Dohlman AW, Black HR, Royall JA. Expired breath hydrogen peroxide is a marker of acute airway inflammation in pediatric patients with asthma. Am Rev Respir Dis 1993; 148: 955-960.

34. Shibuya T, Izuchi K, Kuroiwa A, Harada H, Kumamoto A, Shirakawa K. Study of nonspecific immunity in pregnant women. II. Effects of hormones on chemiluminescence response to peripheral blood phagocytes. Am J Reprod Immunol 1991; 26: 76-81.

35. Miyagi M, Aoyama H, Morishita M, Iwamoto Y. Effects of sex hormones on chemotaxis of human peripheral polymorphonuclear leukocytes and monocytes. J Periodontol 1992; 63: 28-32.

36. Nowak D, Piotrowski WJ, Rozniecki J, Ruta U. The effect of moderate cigarette smoking on serum ceruloplasmin, copper, zinc and C3c levels. Acta Med Pol 1988; 29: 167-174.

37. Taylor JC, Oey L. Ceruloplasmin: plasma inhibitor of the oxidative inactivation of alpha 1 -protease inhibitor. Am Rev Respir Dis 1982; 126: 476-482.

38. Baldwin SR, Simon RH, Grum CM, Ketai LH, Boxer LH, Devall LJ. Oxidant activity in expired breath of patients with adult respiratory distress syndrome. Lancet 1986; i: 11-14. 